\title{
Alternate Partial Root-Zone Drip Nitrogen Fertigation Reduces Residual Nitrate Loss While Improving the Water Use but Not Nitrogen Use Efficiency
}

\author{
Rui Liu 1,2, Peng-Fei Zhu ${ }^{2}$, Yao-Sheng Wang ${ }^{3}$, Zhen Chen ${ }^{1}$, Ji-Rong Zhu ${ }^{2}$, \\ Liang-Zuo Shu ${ }^{1,2 *}$ and Wen-Ju Zhang ${ }^{4 *}$
}

'Zhejiang Provincial Key Laboratory of Plant Evolutionary and Conservation, School of Life Science, Taizhou University, Taizhou, China, ${ }^{2}$ Anhui Key Laboratory of Resource and Plant Biology, School of Life Sciences, Huaibei Normal University, Huaibei, China, ${ }^{3}$ Laboratory of Dryland Agriculture, Institute of Environment and Sustainable Development in Agriculture, Chinese Academy of Agricultural Sciences, Beijing, China, ${ }^{4}$ National Engineering Laboratory for Improving Quality of Arable Land, Institute of Agricultural Resources and Regional Planning, Chinese Academy of Agricultural Sciences, Beijing, China

\section{OPEN ACCESS}

Edited by:

Thorsten M. Knipfer University of British Columbia, Canada

Reviewed by:

Zhen Wang,

China Institute of Water Resources and Hydropower Research, China Harby Mostafa,

Benha University, Egypt

*Correspondence: Liang-Zuo Shu shulz69@163.com Wen-Ju Zhang zhwenju@163.com

Specialty section: This article was submitted to Crop and Product Physiology, a section of the journal

Frontiers in Plant Science

Received: 08 June 2021 Accepted: 15 September 2021

Published: 13 October 2021

Citation:

Liu R, Zhu P-F, Wang Y-S, Chen Z, Zhu J-R, Shu L-Z and Zhang W-J (2021) Alternate Partial Root-Zone Drip Nitrogen Fertigation Reduces Residual Nitrate Loss While Improving the Water Use but Not Nitrogen Use
The efficient utilization of irrigation water and nitrogen is of great importance for sustainable agricultural production. Alternate partial root-zone drip irrigation (APRD) is an innovative water-saving drip irrigation technology. However, the coupling effects of water and nitrogen $(\mathrm{N})$ supply under APRD on crop growth, water and $\mathrm{N}$ use efficiency, as well as the utilization and fate of residual nitrates accumulated in the soil profile are not clear. A simulated soil column experiment where $30-40 \mathrm{~cm}$ soil layer was ${ }^{15} \mathrm{NO}_{3}$-labeled as residual nitrate was conducted to investigate the coupling effects of different water [sufficient irrigation $\left(W_{1}\right)$, two-thirds of the $W_{1}\left(W_{2}\right)$ ] and $N$ [high level $\left(N_{1}\right), 50 \%$ of $N_{1}$ $\left(\mathrm{N}_{2}\right)$ ] supplies under different irrigation modes [conventional irrigation (C), APRD (A)] on tomato growth, irrigation water (IWUE) and $\mathrm{N}$ use efficiencies (NUE), and the fate of residual $\mathrm{N}$. The results showed that, compared with $\mathrm{CW}_{1} \mathrm{~N}_{1}, A \mathrm{AW}_{1} \mathrm{~N}_{1}$ promoted root growth and nitrogen absorption, and increased tomato yield, while the $\mathrm{N}$ absorption and yield did not vary significantly in $A W_{2} N_{1}$. The $N$ absorption in $A W_{2} N_{2}$ decreased by $16.1 \%$, while the tomato yield decreased by only $8.8 \%$ compared with $\mathrm{CW}_{1} \mathrm{~N}_{1}$. The highest IWUE appeared in $A W_{2} N_{1}$, whereas the highest NUE was observed in $A W_{2} N_{2}$, with no significant difference in NUE between $A W_{2} N_{1}$ and $C W_{1} N_{1}$ at the same $N$ supply level. The ${ }^{15} \mathrm{~N}$ accumulation peak layer was almost the same as the originally labeled layer under APRD, whereas it moved 10-20 cm downwards under $\mathrm{CW}_{1} \mathrm{~N}_{1}$. The amount of ${ }^{15} \mathrm{~N}$ accumulated in the $0-40 \mathrm{~cm}$ layer increased with the decreasing irrigation water and nitrogen supply, with an increase of $82.9-141.1 \%$ in APRD compared with that in $\mathrm{CW}_{1} \mathrm{~N}_{1}$. The utilization of the ${ }^{15} \mathrm{~N}$ labeled soil profile by the tomato plants increased by 9-20.5\%, whereas the loss rate of ${ }^{15} \mathrm{~N}$ from the plant-soil column system decreased by $21.3-50.1 \%$ in APRD compared with the $\mathrm{CW}_{1} \mathrm{~N}_{1}$ treatment. Thus, APRD has great potential in saving irrigation water, facilitating water use while reducing the loss of residual nitrate accumulated in the soil profile, but has no significant effect on the NUE absorbed.

Keywords: root growth, fruit yield, irrigation water use efficiency, nitrogen use efficiency, ${ }^{15} \mathrm{~N}$ 


\section{INTRODUCTION}

Water shortage is a great concern that is jeopardizing sustainable development globally, including in China. Water crisis coexists with the low efficiency of irrigation water in agricultural production, which consumes $\sim 70 \%$ of the total freshwater (Mancosu et al., 2015; Kang et al., 2017). Developing water-saving irrigation technologies is an essential and urgent requirement to support the high food demand for the increasing world population. Deficit irrigation and alternate partial root-zone irrigation (APRI) are two water-saving irrigation strategies currently investigated (Kang and Zhang, 2004; Dodd, 2009; Sezen et al., 2019). In deficit irrigation, the amount of water supplied to the whole root zone is less than that of plant evapotranspiration, inducing moderate water stress in the plant which has marginal effects on yield formation (Dodd, 2009). In APRI, irrigation is supplied only to half of the root system, leaving the other half dry till the next irrigation occurs. The repeated alternation of wetting/drying in the two root zones in APRI induces an abscisic acid (ABA)-based root-to-shoot chemical signaling, hydraulic signals, and an increased xylem sap $\mathrm{pH}$ to regulate the stomatal opening thereby increasing water use efficiency (WUE) (Kang and Zhang, 2004; Hu et al., 2011; Pérez-Pérez et al., 2018). For many plant species including cotton, corn, tomato, potato, cucumber, grape, and apple, APRI has been demonstrated to be an efficient water-saving irrigation technology that outperforms deficit irrigation by maintaining the yield and improving the WUE substantially (Kang and Zhang, 2004; Shahnazari et al., 2007; Dodd, 2009; Yactayo et al., 2013; Jovanovic and Stikic, 2018; Sarker et al., 2019). The main form in APRI application is the alternate furrow irrigation or alternate watering to different sides of the plants (Yactayo et al., 2013; Zhang et al., 2014; Sarker et al., 2019, 2020; Khalili et al., 2020). However, it is a time-consuming and laborious process to manipulate the furrows or to manually switch the irrigation sides, which limits its use in practice. With the popularization of drip fertilization technology, an emerging new kind of APRI, named alternate partial root-zone drip irrigation (APRD) is formed by combining drip irrigation with APRI ( $D u$ et al., 2008a,b; Topak et al., 2016; Sezen et al., 2019). This form of APRI is not only easy to implement but also potentially has the advantages of both APRI and drip irrigation in improving WUE and yield (Topak et al., 2016; Sezen et al., 2019; Liu et al., 2020).

Nitrogen is an important macro-nutrient for crop growth and yield. However, the excessive application of nitrogen $(\mathrm{N})$ fertilizer not only reduces fertilizer use efficiency but also produces many environmental problems, adversely impacting the quality of vegetables and fruit trees (Zhu and Chen, 2002; Gong et al., 2011). In addition, excessive fertilization leads to the accumulation of high amounts of residual nitrate in the soil profile of farmlands, which could leach into the groundwater, causing environmental problems (Zhu and Chen, 2002; Gathumbi et al., 2003). Therefore, increasing the $\mathrm{N}$ use efficiency (NUE) and reducing the soil residual nitrate accumulation and its leaching into the groundwater is an important issue to be resolved (Gathumbi et al., 2003).
Alternate partial root-zone irrigation can facilitate the accumulation of nitrate in the topsoil, promote the absorption of $\mathrm{N}$ by plants, and reduce the potential risk of nitrate leaching (Tafteh and Sepaskhah, 2012; Wang et al., 2014, 2020; Hou et al., 2017). However, whether the NUE in plants has improved under APRI is unclear. Although APRD is a promising new technology, the coupling effects of different water and $\mathrm{N}$ supplies on the movement and utilization of the residual nitrate accumulated in the soil profile under APRD are not known. Furthermore, the residual nitrate accumulated $30-40 \mathrm{~cm}$ under APRI also received little attention. Root growth and distribution decreased sharply beneath $20 \mathrm{~cm}$, while it accumulated higher amounts of residual nitrate in the 20-40 cm layer (Zhang et al., 2014; Liu et al., 2020). Therefore, in the present study, a soil column experiment was conducted with the ${ }^{15} \mathrm{~N}$-labeled $\mathrm{K}^{15} \mathrm{NO}_{3}$ as the residual nitrate in the $30-40 \mathrm{~cm}$ soil layer, to investigate the effects of different water and nitrogen supply on the growth, WUE, NUE, and the fate of residual nitrate accumulated in the soil profile of tomato plants, a common greenhouse vegetable, under APRD. The outcome of this study would be of great significance to guide efficient utilization of water and $\mathrm{N}$ resources and reduce environmental risk by sustainable agricultural production.

\section{MATERIALS AND METHODS}

\section{Experimental Site}

The experimental site is located in a steel-framed vegetable greenhouse in Xuji Village $\left(116^{\circ} 46^{\prime} \mathrm{E}, 33^{\circ} 58^{\prime} \mathrm{N}\right)$, Duji District, Huaibei City, Anhui Province, China. It belongs to a typical temperate humid climate, with an average annual relative humidity of $71 \%$, an annual average frost-free period of 202 days, and sunshine hours of $2315.8 \mathrm{~h}$. The experiment was initiated on February 28 and finished on June 25, 2017. The experimental soil was sandy loam (Shu et al., 2020). The pH of the soil was 7.3, with $26.2 \%$ (gravimetric) or $0.341 \mathrm{~cm}^{-3}$ field water capacity, $1.6 \mathrm{~g} \mathrm{~kg}^{-1}$ total $\mathrm{N}, 37.4 \mathrm{mg} \mathrm{kg}^{-1}$ nitrate $\mathrm{N}, 0.6 \mathrm{~g} \mathrm{~kg}^{-1}$ total phosphorus (P), and $1.3 \mathrm{~g} \mathrm{~cm}^{-3}$ soil bulk density.

\section{Experimental Treatments}

The experiment was performed using soil columns which were made using cylindrical aluminum drums (Figure 1) as described in our previous studies (Wang et al., 2019, 2020; Liu et al., 2020). A ditch was dug in the center of the greenhouse and the soil from the layers $0-20,20-40,40-60$, and $60-100 \mathrm{~cm}$ were separated. Eighteen homemade bottomless cylindrical aluminum drums with a height of $105 \mathrm{~cm}$ and a diameter of $45 \mathrm{~cm}$ were put vertically to a depth of $100 \mathrm{~cm}$ along the ditch, $15 \mathrm{~cm}$ apart from each other. Then the sieved dry soil (passed through a $2 \mathrm{~mm}$ sieve) from the original layers was backfilled to the drums and watered to its $90 \%$ field capacity layer by layer. While filling the soil columns, the ditch area outside the drums was also filled. In the $30-40 \mathrm{~cm}$ layer of each column, the soil was mixed and labeled with $11.9 \mathrm{~g} \mathrm{~K}^{15} \mathrm{NO}_{3}$ (the abundance of ${ }^{15} \mathrm{~N}$ was $20.3 \%$, provided by the Shanghai Research Institute of Chemical Industry). All the $\mathrm{P}$ and potassium fertilizers were supplied as basal fertilizers and were mixed with the top $0-20 \mathrm{~cm}$ soil layer as $\mathrm{KH}_{2} \mathrm{PO}_{4}$ and $\mathrm{K}_{2} \mathrm{SO}_{4}$ at the rate of $200 \mathrm{mg} \mathrm{P}_{2} \mathrm{O}_{5} \mathrm{~kg}^{-1}$ and $300 \mathrm{mg} \mathrm{K}_{2} \mathrm{O} \mathrm{kg}^{-1}$, 


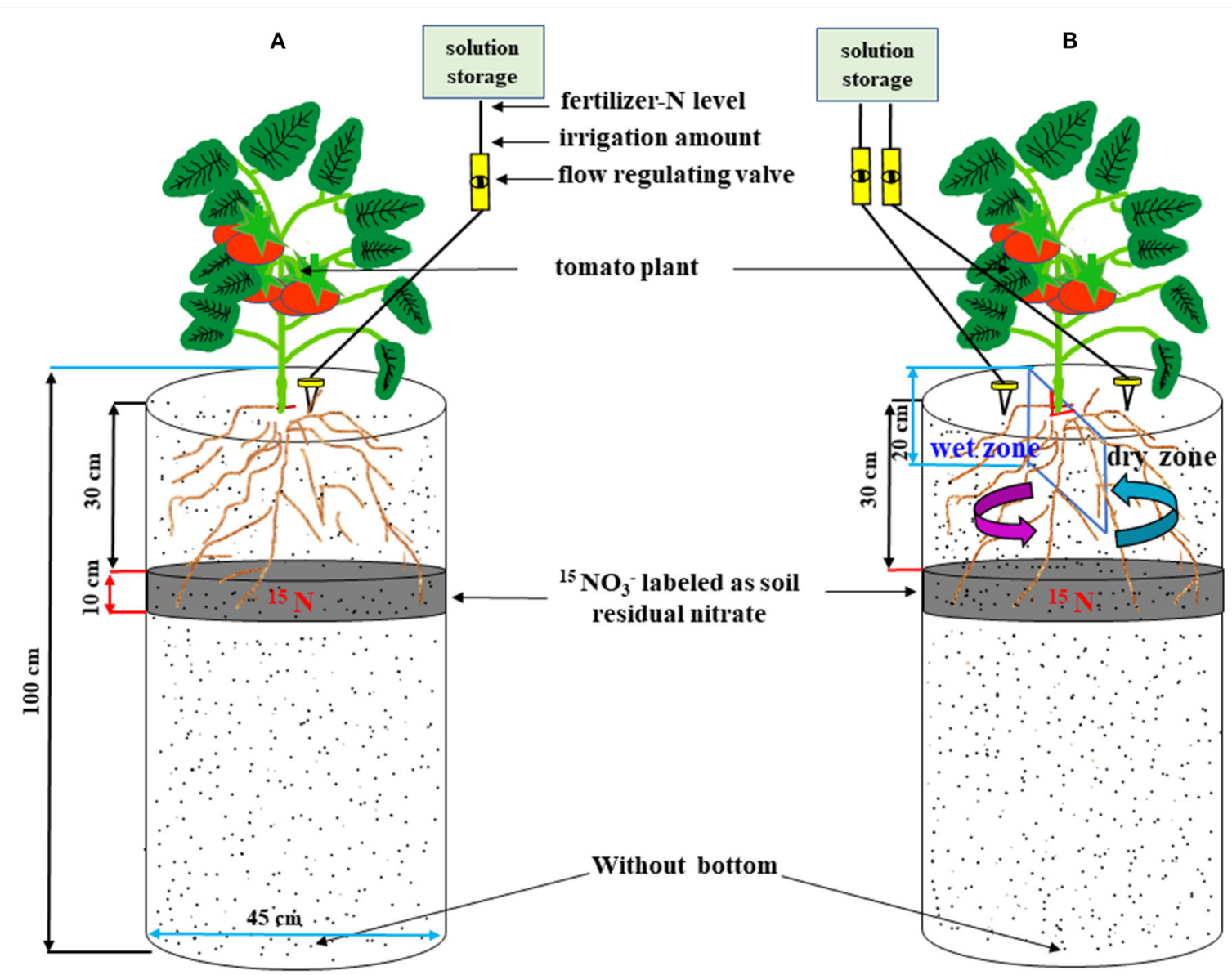

FIGURE 1 | The schematic view of the soil column design for conventional drip irrigation (A) and alternate partial root-zone drip irrigation (B).

respectively. Nitrogen fertilizer was supplied by fertigation while planting the tomatoes. To avoid the surface flow of irrigated water between the root compartments as indicated previously in the pot APRI experiments (Li et al., 2010; Wang et al., 2010), the top 0$20 \mathrm{~cm}$ soil in the APRD column was separated into two equal compartments by inserting a plastic film vertically in the center (Hou et al., 2017; Liu et al., 2020). A gap of $5 \times 5 \mathrm{~cm}$ size was cut in the center of the plastic film to allow the transplanting of tomato seedlings.

The method for supplying water and $\mathrm{N}$ was the same as in our previous study (Liu et al., 2020). Briefly, a 5 L plastic bucket was suspended at a height of $1.8 \mathrm{~m}$ above the soil column (Figure 1). The water and $\mathrm{N}$ fertilizers were delivered from the bucket to the surface of the soil column through a medical infusion tube with needles (specification 16G, aperture $1.3 \mathrm{~mm}$ ). On February 28, 2017, 50-day-old tomato (Lycopersicon esculentum Mill., cv. Zhongyan No. 958) seedlings of uniform size were transplanted in the center of the columns, with one seedling for each column. The surface layer of the column was covered with a plastic film after transplanting to reduce water evaporation. The plants were watered with conventional drip irrigation during the plant re-establishment stage. The water and $\mathrm{N}$ fertilizer treatments were initiated 18 days after transplantation (March 18). The four treatments included $\mathrm{CW}_{1} \mathrm{~N}_{1}, \mathrm{AW}_{1} \mathrm{~N}_{1}, \mathrm{AW}_{2} \mathrm{~N}_{1}$, and $\mathrm{AW}_{2} \mathrm{~N}_{2}$, where $C$ represented conventional drip irrigation, $A$ represented $\mathrm{APRD}, \mathrm{W}_{1}$ and $\mathrm{W}_{2}$ represented sufficient and deficient irrigation, and $\mathrm{N}_{1}$ and $\mathrm{N}_{2}$ represented high $\mathrm{N}$ and low $\mathrm{N}$ application rate, respectively. Each treatment was replicated four times.

In the $\mathrm{CW}_{1} \mathrm{~N}_{1}$ treatment, the soil in $0-20 \mathrm{~cm}$ (seedling stage) or $0-30 \mathrm{~cm}$ (after flowering stage) was irrigated to $90 \%$ of the field capacity whenever the soil water content dropped to $65 \%$ of the field capacity. The irrigation amount of $\mathrm{W}_{1}\left(\mathrm{CW}_{1} \mathrm{~N}_{1}\right)$ was calculated according to the method described by Liu et al. (2020). Irrigation was applied to all treatments when $\mathrm{CW}_{1} \mathrm{~N}_{1}$ was irrigated. For the deficient irrigation treatment, two-thirds of the $\mathrm{W}_{1}\left(\mathrm{~W}_{2}\right)$ irrigation amount was applied. For the $\mathrm{N}$ application amount, $\mathrm{N}_{1}$ was calculated as supplying $\mathrm{N}$ at $240 \mathrm{mg} \mathrm{kg}^{-1}$ to the $0-20 \mathrm{~cm}$ soil layer in the column, and $\mathrm{N}_{2}$ received $50 \%$ of the $\mathrm{N}_{1}$ level. The $\mathrm{N}$ fertilizer was supplied as urea at $8.30 \mathrm{~g}$ urea per column for the $\mathrm{N}_{1}$ level during the experiment. In the $\mathrm{CW}_{1} \mathrm{~N}_{1}$ treatment, fertigation was supplied to a location 5$\mathrm{cm}$ away from the plants through needles (Figure 1A). In the APRD treatment $\left(\mathrm{AW}_{1} \mathrm{~N}_{1}, \mathrm{AW}_{2} \mathrm{~N}_{1}\right.$, and $\left.\mathrm{AW}_{2} \mathrm{~N}_{2}\right)$, fertigation was supplied alternately to only one compartment in the center 
of each irrigation event, letting the other soil compartment dry. At the next irrigation, the fertigation was shifted to the previously dry compartment, letting the previously irrigated compartment dry (Figure 1B). The $\mathrm{N}$ fertigation interval was at 4-10 days depending on the soil water content in the soil columns. There were a total of fourteen drip fertigation events in the present study, with 0.593 or $0.296 \mathrm{~g}$ urea at each fertigation for the $\mathrm{N}_{1}$ or $\mathrm{N}_{2}$ treatment, respectively, forming seven alternating wetting-drying fertigation cycles in each root compartment of the $\mathrm{AW}_{1} \mathrm{~N}_{1^{-}}, \mathrm{AW}_{2} \mathrm{~N}_{1^{-}}$, and $\mathrm{AW}_{2} \mathrm{~N}_{2}$-treated soil columns.

To monitor the changes in the soil water content and to determine when to start the irrigation, two soil columns without the ${ }^{15} \mathrm{~N}$ labeling were set as the reference and were managed as the $\mathrm{CW}_{1} \mathrm{~N}_{1}$ treatment. A time-domain reflection meter (TDR) instrument (TRIME-PICO-IPH-TDR, IMKO, Germany) was buried in the reference column at a depth of $0-100 \mathrm{~cm}$. In addition, a portable TDR soil moisture meter was also used for examining the soil water content in the $0-20 \mathrm{~cm}$ soil layer. When the soil moisture content declined to $65 \%$ of the field capacity, irrigation was applied to all columns. The amount of water supplied was $8.5 \mathrm{~L}$ for each column before different drip fertigation treatments were initiated. After that, $42.7 \mathrm{~L}$ or $28.2 \mathrm{~L}$ of irrigation water was supplied to the treatments as $\mathrm{W}_{1}$ and $\mathrm{W}_{2}$, respectively. Therefore, the $\mathrm{W}_{2}$ treatment saved $28.3 \%$ of irrigation water in the whole plant growth period compared with that of $W_{1}$. The plants had five ears of fruit per plant and there were three fruits per ear. The tomato plants were finally harvested on June 25, 2017.

\section{Measurements and Methods}

On May 5, after removing the apical buds, the plant height and stem diameter were measured. The plant height was measured with a tape. The diameter of the stem $(3 \mathrm{~cm}$ above the ground) was measured with a $0.01 \mathrm{~mm}$ precision digital vernier caliper (Shanghai Meinaite Industrial Inc., Shanghai, China).

The fallen leaves on the ground were collected during plant growth, and the fruits were harvested successively to maturity. The plants were harvested on June 25, 2017, and were divided into leaves, stems, and fruits. All the fresh samples were weighed and then oven-dried at $105^{\circ} \mathrm{C}$ for $30 \mathrm{~min}$ immediately after sampling and thereafter dried at $70^{\circ} \mathrm{C}$ to constant mass. The biomass of the leaves included the fallen leaves. The fruit yield was the cumulative value of fruits collected in different batches.

After harvest, the soil outside the soil columns was dug out, then the aluminum drum was exposed and cut longitudinally. About $20 \mathrm{~cm}$ per layer of soil was taken out from the drums horizontally. The roots were collected carefully using tweezers and then cleaned with distilled water. After root samples in each layer were collected, the soil was mixed thoroughly in a basin and soil samples were taken. A subsample was used to determine the soil water content immediately. The remaining soil samples were air-dried and then used for determining the total $\mathrm{N}$ content and the soil ${ }^{15} \mathrm{~N}$.

The roots were scanned by a root scanner (Epson Perfection V700 Photo, Epson, Japan), and the root length, diameter, and surface area were analyzed with a WinRhizoPro Vision 5.0
(Regent Instruments, Inc., Quebec, Canada). After scanning, the roots in each layer were dried in the oven to constant mass.

Both the plant and soil samples were ground and passed through a $0.25-\mathrm{mm}$ sieve. The concentrations of the total $\mathrm{N}$ and ${ }^{15} \mathrm{~N}$ were analyzed using mass spectrometry (isoprime100, Elementar Analysensysteme $\mathrm{GmbH}$, Germany) coupled with an elemental analyzer (Vario pyro cube, Analysensysteme $\mathrm{GmbH}$, Germany). The total $\mathrm{N}$ absorption was calculated by $\mathrm{N}$ concentration and the dry mass of each organ.

Irrigation water use efficiency $\left(\mathrm{kg} \cdot \mathrm{m}^{-3}\right)=$ fresh mass of tomato fruit/total irrigation water used. NUE $\left(\mathrm{g} \cdot \mathrm{g}^{-1}\right)=$ dry mass of tomato fruit/ $\mathrm{N}$ accumulated in the plant. ${ }^{15} \mathrm{~N}$ absorption (mg) $=\left(\right.$ atom $\%{ }^{15} \mathrm{~N}$ excess of total $\mathrm{N}$ in plant $) \times($ total $\mathrm{N}$ in the plant $)$. The utilization of ${ }^{15} \mathrm{~N}$ by the plants $(\%)=\left(\right.$ atom $\%{ }^{15} \mathrm{~N}$ excess of total $\mathrm{N}$ in the plant) $\times\left(\right.$ total $\mathrm{N}$ in the plant) $/$ (amount of ${ }^{15} \mathrm{~N}$ labeled). Soil ${ }^{15} \mathrm{~N}$ accumulation $(\mathrm{mg})=\left(\right.$ atom $\%{ }^{15} \mathrm{~N}$ excess of soil total $\mathrm{N}) \times($ total $\mathrm{N}$ per soil layer $)$.

\section{Statistical Analysis}

The experimental data were analyzed using a one-way ANOVA with the SPSS software (IBM, Armonk, NY, USA) and average comparisons were made using Duncan's multiple range test at $P$ $\leq 0.05$. The data were expressed as mean \pm standard error.

\section{RESULTS}

\section{Effects of Irrigation and Nitrogen Supply on Plant Growth}

The irrigation methods and the amount of irrigation water or $\mathrm{N}$ supplied did not affect the height of the tomato plants (Figure 2A), but significantly affected the stem diameter (Figure 2B). Compared with the $\mathrm{CW}_{1} \mathrm{~N}_{1}$ treatment, the stem diameter under the $\mathrm{AW}_{1} \mathrm{~N}_{1}$ treatment increased by $1.6 \%$, whereas it decreased by 3.3 and $5.5 \%$ under the $\mathrm{AW}_{2} \mathrm{~N}_{1}$ and $\mathrm{AW}_{2} \mathrm{~N}_{2}$ treatment, respectively. Under APRD, a reduction in one-third of the irrigation water decreased the stem diameter by $4.8 \%$ in the $\mathrm{AW}_{2} \mathrm{~N}_{1}$ treatment compared with $\mathrm{AW}_{1} \mathrm{~N}_{1}$.

Compared with $\mathrm{CW}_{1} \mathrm{~N}_{1}$, the leaf and total biomass and fruit mass in the $A W_{1} N_{1}$ treatment increased significantly except for the stem dry mass (Table 1). Under APRD, the stem, leaf, and total dry biomass and fruit mass in the $\mathrm{AW}_{2} \mathrm{~N}_{1}$ treatment were significantly lower than those of $\mathrm{AW}_{1} \mathrm{~N}_{1}$. Compared with the $\mathrm{CW}_{1} \mathrm{~N}_{1}$ treatment, the total biomass in the $\mathrm{AW}_{2} \mathrm{~N}_{1}$ treatment decreased by $5.8 \%$, while the fruit mass did not decrease significantly. Under the APRD with $\mathrm{W}_{2}$ and a reduction in $\mathrm{N}$ fertilizer by $50 \%$, there were no significant effects on the fruit yield and leaf biomass but decreased the stem biomass and total biomass by $8.4 \%$ on average $\left(\mathrm{AW}_{2} \mathrm{~N}_{2}\right.$ vs. $\left.\mathrm{AW}_{2} \mathrm{~N}_{1}\right)$. Compared with $\mathrm{CW}_{1} \mathrm{~N}_{1}$, the fruit yield in $\mathrm{AW}_{2} \mathrm{~N}_{2}$ decreased by only $8.8 \%$, even though the irrigation amount and nitrogen application rate were both decreased substantially in the $\mathrm{AW}_{2} \mathrm{~N}_{2}$.

\section{Effects of Irrigation and Nitrogen Supply on Root Growth and Distribution}

Compared with $\mathrm{CW}_{1} \mathrm{~N}_{1}, \mathrm{AW}_{1} \mathrm{~N}_{1}$ increased the root length and surface area by 6.8 and $8.7 \%$, respectively, while there was no significant difference in the root dry mass (Table 2). There was 

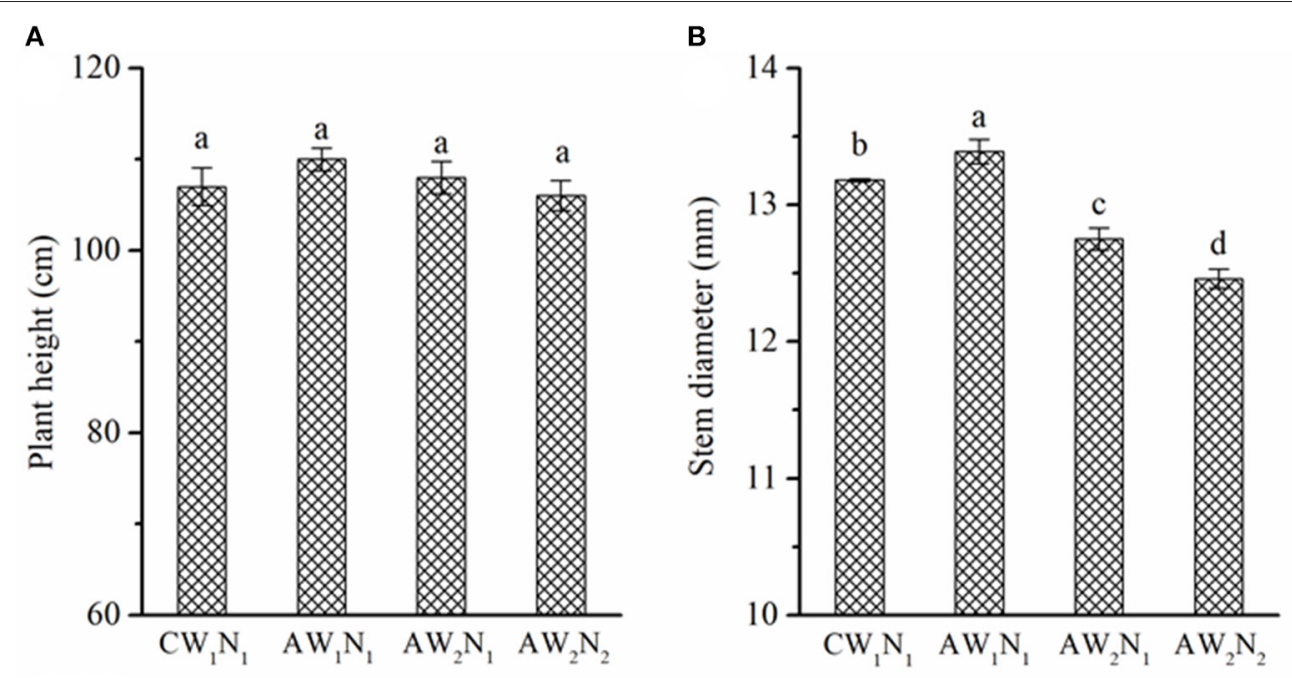

FIGURE 2 | The effects of irrigation and nitrogen $(\mathrm{N})$ supply on the plant height $(\mathbf{A}, \mathrm{cm})$ and stem diameter $(\mathbf{B}$, mm) of tomato plants under alternate partial root-zone drip irrigation. Values are the means \pm SE. Different lowercase letters in the columns denote significant differences among the treatments $(P \leq 0.05)$.

TABLE 1 | Effects of irrigation and nitrogen ( $\mathrm{N})$ supply on tomato biomass ( $\mathrm{g} \mathrm{plant}^{-1}$ ) and yield (g plant ${ }^{-1}$ ) under alternate partial root-zone drip $\mathrm{N}$ fertigation.

\begin{tabular}{|c|c|c|c|c|c|}
\hline Treatments & $\begin{array}{c}\text { Stem } \\
\text { dry mass }\end{array}$ & $\begin{array}{c}\text { Leaf } \\
\text { dry mass }\end{array}$ & $\begin{array}{c}\text { Fruit } \\
\text { dry mass }\end{array}$ & $\begin{array}{c}\text { Fruit } \\
\text { fresh mass }\end{array}$ & $\begin{array}{c}\text { Total } \\
\text { biomass* }\end{array}$ \\
\hline $\mathrm{CW}_{1} \mathrm{~N}_{1}$ & $91.0 \pm 2.8 a b$ & $80.7 \pm 1.0 b$ & $220.9 \pm 3.9 b$ & $4270 \pm 29 b$ & $403.2 \pm 5.4 b$ \\
\hline $\mathrm{AW}_{1} \mathrm{~N}_{1}$ & $95.3 \pm 0.8 a$ & $88.0 \pm 0.7 a$ & $259.5 \pm 2.5 a$ & $4573 \pm 24 a$ & $453.9 \pm 3.2 a$ \\
\hline $\mathrm{AW}_{2} \mathrm{~N}_{1}$ & $87.6 \pm 0.3 b$ & $72.7 \pm 2.7 c$ & $208.9 \pm 7.8 \mathrm{bc}$ & $4117 \pm 64 b$ & $379.7 \pm 7.1 \mathrm{c}$ \\
\hline $\mathrm{AW}_{2} \mathrm{~N}_{2}$ & $77.8 \pm 1.8 \mathrm{c}$ & $68.0 \pm 1.6 c$ & $202.6 \pm 2.7 c$ & $3874 \pm 38 c$ & $358.0 \pm 2.5 d$ \\
\hline
\end{tabular}

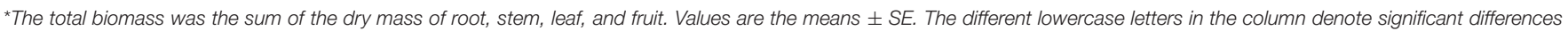
among the treatments $(P \leq 0.05)$.

TABLE 2 | The effects of irrigation and N supply on the mass, length, and surface area of tomato roots under alternate partial root-zone drip $\mathrm{N}$ fertigation.

\begin{tabular}{lccc}
\hline Treatments & $\begin{array}{c}\text { Dry mass } \\
\text { (g plant }\end{array}$ & $\begin{array}{c}\text { Length } \\
\text { (m } \text { plant }^{-1} \text { ) }\end{array}$ & $\begin{array}{c}\text { Surface area } \\
\text { (cm }^{\mathbf{2}} \text { plant }^{-1} \text { ) }\end{array}$ \\
\hline $\mathrm{CW}_{1} \mathrm{~N}_{1}$ & $10.60 \pm 0.12 \mathrm{a}$ & $226.3 \pm 0.6 \mathrm{~b}$ & $9009 \pm 153 \mathrm{~b}$ \\
$\mathrm{AW}_{1} \mathrm{~N}_{1}$ & $11.11 \pm 0.09 \mathrm{a}$ & $241.8 \pm 4.3 \mathrm{a}$ & $9792 \pm 150 \mathrm{a}$ \\
$\mathrm{AW}_{2} \mathrm{~N}_{1}$ & $10.58 \pm 0.13 \mathrm{a}$ & $230.6 \pm 3.8 \mathrm{~b}$ & $9243 \pm 118 \mathrm{~b}$ \\
$\mathrm{AW}_{2} \mathrm{~N}_{2}$ & $9.60 \pm 0.39 \mathrm{~b}$ & $221.6 \pm 1.2 \mathrm{~b}$ & $7882 \pm 160 \mathrm{c}$ \\
\hline
\end{tabular}

The values are the means $\pm S E$. The different lowercase letters in the columns denote significant differences among the treatments $(P \leq 0.05)$.

no significant difference in the root dry mass, length, and surface area between the $\mathrm{AW}_{2} \mathrm{~N}_{1}$ and $\mathrm{CW}_{1} \mathrm{~N}_{1}$ treatments. However, the root length and root surface area were lower in $\mathrm{AW}_{2} \mathrm{~N}_{1}$ than those of $\mathrm{AW}_{1} \mathrm{~N}_{1}$. The $\mathrm{AW}_{2} \mathrm{~N}_{2}$ treatment had no significant influence on the root length but decreased the root dry mass by $9.4 \%$ and the root surface area by $12.5 \%$ compared with the $\mathrm{CW}_{1} \mathrm{~N}_{1}$ treatment.

Compared with the $\mathrm{CW}_{1} \mathrm{~N}_{1}$ treatment, the root mass in the $\mathrm{AW}_{1} \mathrm{~N}_{1}$ treatment increased significantly in the $0-40 \mathrm{~cm}$ soil layer, which was similar in the $40-80 \mathrm{~cm}$ but decreased in the $80-100 \mathrm{~cm}$ soil layer (Figure 3A). The $\mathrm{AW}_{2} \mathrm{~N}_{1}$ had a similar root mass in the $0-60 \mathrm{~cm}$ soil layer compared with the $\mathrm{CW}_{1} \mathrm{~N}_{1}$ treatment. The root mass under APRD in the $80-100 \mathrm{~cm}$ soil layer was reduced by $21.4-45.8 \%$ compared with that under the $\mathrm{CW}_{1} \mathrm{~N}_{1}$ treatment.

Compared with the $\mathrm{CW}_{1} \mathrm{~N}_{1}$ treatment, the root length in the $\mathrm{AW}_{1} \mathrm{~N}_{1}$ treatment showed no significant difference in the $0-40 \mathrm{~cm}$ soil layer but increased by $8.2 \%$ significantly in the $40-100 \mathrm{~cm}$ (Figure 3B). There was no significant difference in the total root length or root length in different soil layers between $\mathrm{AW}_{2} \mathrm{~N}_{1}$ and $\mathrm{AW}_{2} \mathrm{~N}_{2}$ except in the $60-80 \mathrm{~cm}$ soil layer, where the root length increased significantly in $A W_{2} N_{1}$. However, the root length below $40 \mathrm{~cm}$ in the soil profile decreased significantly in $\mathrm{AW}_{2} \mathrm{~N}_{1}$ and $\mathrm{AW}_{2} \mathrm{~N}_{2}$ compared with that of $\mathrm{AW}_{1} \mathrm{~N}_{1}$ (Table 2 and Figure 3B).

Compared with $\mathrm{CW}_{1} \mathrm{~N}_{1}$, the root diameter tended to decrease under the APRD treatments (Figure 3C), by $6.5 \%$ on average in $\mathrm{AW}_{1} \mathrm{~N}_{1}$ in the $20-80 \mathrm{~cm}$ layer, and 10 and $14.4 \%$ in $0-100 \mathrm{~cm}$ in $\mathrm{AW}_{2} \mathrm{~N}_{1}$ and $\mathrm{AW}_{2} \mathrm{~N}_{2}$, respectively.

The variations of the root surface area among the treatments were similar to that of the root length (Figure 3D). Compared with $\mathrm{CW}_{1} \mathrm{~N}_{1}$, the root surface area in the soil profile of $\mathrm{AW}_{1} \mathrm{~N}_{1}$ 


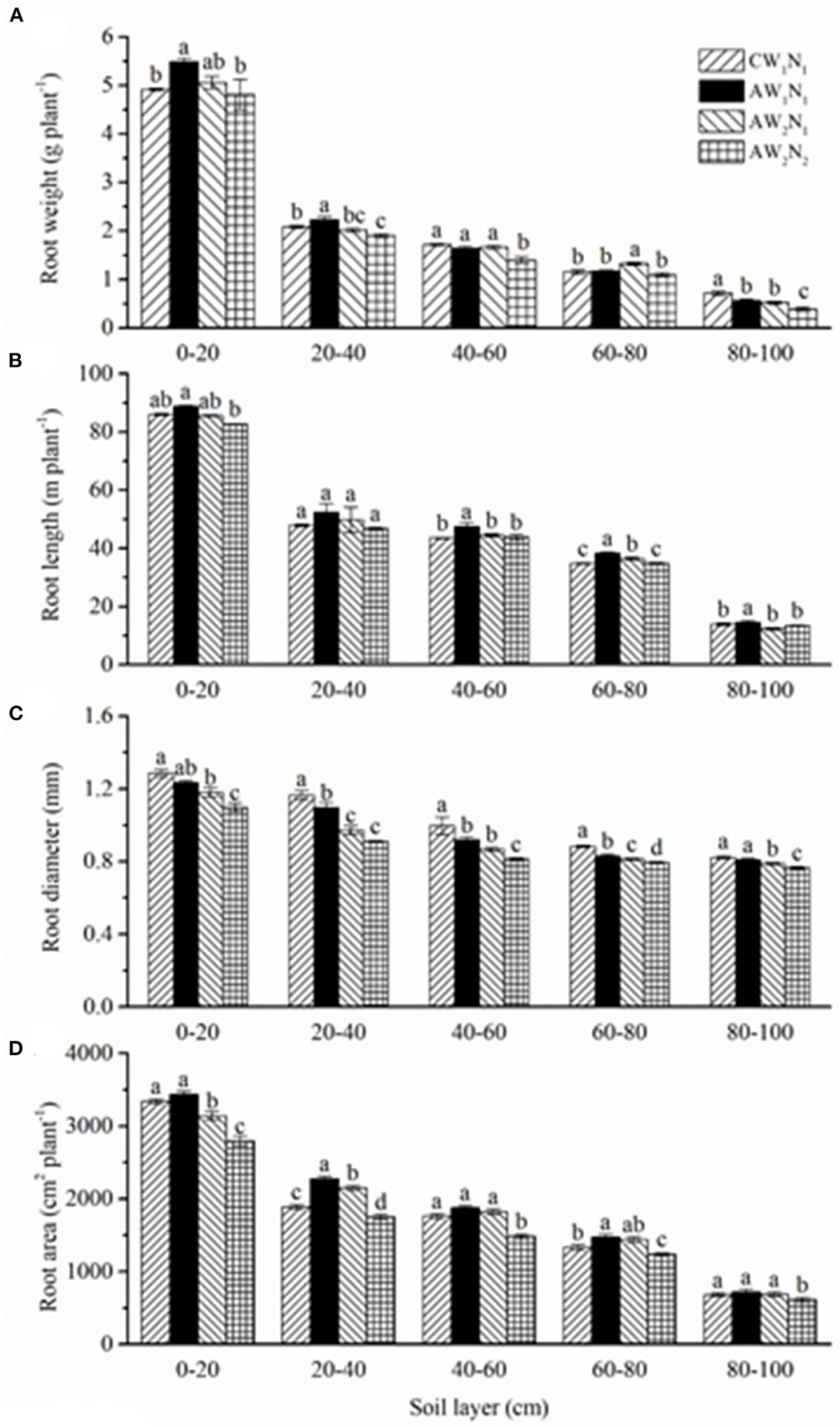

FIGURE 3 | The effects of irrigation and N supply on root growth and distribution in soil layers under alternate partial root-zone drip irrigation. (A) Root weight (g plant ${ }^{-1}$ ), (B) root length ( $\mathrm{m}$ plant $\left.{ }^{-1}\right)$, (C) toot diameter $(\mathrm{mm})$ and $(\mathbf{D})$ root area $\left(\mathrm{cm}^{2}\right.$ plant $\left.^{-1}\right)$. Values are the means \pm SE. Different lowercase letters in the columns denote significant differences among the treatments $(P \leq 0.05)$.

tended to increase in the $0-80 \mathrm{~cm}$ layer and showed a significant difference in $20-80 \mathrm{~cm}$. Reduction of water and/or $\mathrm{N}$ fertilizer under APRD decreased the root surface area, but this decrease became less obvious with the increase in soil depth. Compared with $\mathrm{CW}_{1} \mathrm{~N}_{1}$, the root surface area in the $\mathrm{AW}_{2} \mathrm{~N}_{2}$ treatment decreased significantly in different soil layers except in $60-80 \mathrm{~cm}$. 
Effects of Irrigation and Nitrogen Supply on Water, Nitrogen, and ${ }^{15} \mathrm{~N}$ Use Efficiency

At the same fertigation level, $\mathrm{AW}_{1} \mathrm{~N}_{1}$ increased the $\mathrm{N}$ absorption by $13.8 \%$, and irrigation water use efficiency (IWUE) by $7.1 \%$ compared with that of $\mathrm{CW}_{1} \mathrm{~N}_{1}$. However, there was no significant difference in the NUE between $\mathrm{CW}_{1} \mathrm{~N}_{1}$ and $\mathrm{AW}_{1} \mathrm{~N}_{1}$ (Table 3). Under APRD, the total $\mathrm{N}$ absorption by the tomato plants decreased with a reduction in irrigation amount and $\mathrm{N}$ level, with the highest $\mathrm{N}$ absorption observed in $\mathrm{AW}_{1} \mathrm{~N}_{1}$. The IWUE of plants treated with $\mathrm{AW}_{2} \mathrm{~N}_{1}$ was highest among the treatments. Compared with $\mathrm{CW}_{1} \mathrm{~N}_{1}, \mathrm{AW}_{2} \mathrm{~N}_{1}$ increased the IUWE by $35.6 \%$, but no significant difference in NUE was observed. The $\mathrm{AW}_{2} \mathrm{~N}_{2}$ treatment had the highest NUE among all treatments, being $9.4 \%$ higher than that of $\mathrm{CW}_{1} \mathrm{~N}_{1}$. Similarly, the IWUE was also higher in $\mathrm{AW}_{2} \mathrm{~N}_{2}$ than those in $\mathrm{CW}_{1} \mathrm{~N}_{1}$ and $\mathrm{AW}_{1} \mathrm{~N}_{1}$ treatments.

There was no significant difference in the total ${ }^{15} \mathrm{~N}$ absorption and ${ }^{15} \mathrm{~N}$ recovery rate between the treatments $\mathrm{CW}_{1} \mathrm{~N}_{1}$ and $\mathrm{AW}_{1} \mathrm{~N}_{1}$ (Figure 4). The ${ }^{15} \mathrm{~N}$ absorption and recovery rate in $\mathrm{AW}_{2} \mathrm{~N}_{1}$ was the highest among all the treatments, which

TABLE 3 | The effects of irrigation and $\mathrm{N}$ supply on the total plant $\mathrm{N}$ absorption, irrigation water (IWUE), and N (NUE) use efficiency under alternate partial root-zone drip $\mathrm{N}$ fertigation.

\begin{tabular}{|c|c|c|c|c|}
\hline Treatments & $\begin{array}{c}\text { Total } \mathbf{N} \\
\left(\text { (g plant }^{-1}\right)\end{array}$ & $\begin{array}{c}\text { NUE } \\
\left(\mathbf{g} \cdot \mathbf{g}^{-1}\right)\end{array}$ & $\begin{array}{c}\text { IWUE } \\
\left(\mathbf{k g} \cdot \mathrm{m}^{-3}\right)\end{array}$ & $\begin{array}{c}\text { IWUE } \\
\left(\mathrm{kg} \cdot \mathrm{ha}^{-1} \cdot \mathrm{mm}^{-1}\right)\end{array}$ \\
\hline $\mathrm{CW}_{1} \mathrm{~N}_{1}$ & $8.41 \pm 0.10 b$ & $26.26 \pm 0.31 b c$ & $83.41 \pm 0.56 d$ & $834 \pm 6 d$ \\
\hline$A W_{1} N_{1}$ & $9.57 \pm 0.11 a$ & $27.12 \pm 0.31 b$ & $89.34 \pm 0.47 c$ & $893 \pm 5 c$ \\
\hline $\mathrm{AW}_{2} \mathrm{~N}_{1}$ & $8.21 \pm 0.23 b$ & $25.43 \pm 0.32 c$ & $113.12 \pm 1.44 a$ & $1131 \pm 14 a$ \\
\hline $\mathrm{AW}_{2} \mathrm{~N}_{2}$ & $7.06 \pm 0.14 c$ & $28.74 \pm 0.49 a$ & $105.53 \pm 1.86 b$ & $1055 \pm 19 b$ \\
\hline
\end{tabular}

The values are the means $\pm S E$. The different lowercase letters in the columns denote significant differences among the treatments $(P \leq 0.05)$. increased by $20.5 \%$ compared with that of $\mathrm{CW}_{1} \mathrm{~N}_{1}$. The total ${ }^{15} \mathrm{~N}$ absorption and recovery rate showed no significant difference among the treatments of $\mathrm{AW}_{2} \mathrm{~N}_{2}, \mathrm{AW}_{1} \mathrm{~N}_{1}$, and $\mathrm{CW}_{1} \mathrm{~N}_{1}$.

\section{Effects of Irrigation and Nitrogen Supply on ${ }^{15} \mathrm{~N}$ Distribution in Different Soil Layers}

The ${ }^{15} \mathrm{~N}$ was labeled in the $30-40 \mathrm{~cm}$ layer of the soil columns. However, ${ }^{15} \mathrm{~N}$ was also found in the $0-20 \mathrm{~cm}$ layer after harvest (Figure 5), indicating that ${ }^{15} \mathrm{~N}$ has moved upward and was taken up by plants. In the $0-20 \mathrm{~cm}$ soil layer, the ${ }^{15} \mathrm{~N}$ accumulation in the $\mathrm{CW}_{1} \mathrm{~N}_{1}$ treatment was significantly lower than that of the APRD treatment. In the $20-40 \mathrm{~cm}$ soil layer, the ${ }^{15} \mathrm{~N}$ accumulation of $\mathrm{CW}_{1} \mathrm{~N}_{1}$ accounted for only $19.3 \%$ of the total ${ }^{15} \mathrm{~N}$ labeled, while $\mathrm{AW}_{1} \mathrm{~N}_{1}, \mathrm{AW}_{2} \mathrm{~N}_{1}$, and $\mathrm{AW}_{2} \mathrm{~N}_{2}$ accounted for $36.6,38.6$, and $49.7 \%$ of the applied ${ }^{15} \mathrm{~N}$, respectively.

The distance between the soil layer where the ${ }^{15} \mathrm{~N}$ accumulation peak appeared after plant harvest and the layer labeled with $\mathrm{K}^{15} \mathrm{NO}_{3}$ at the beginning of the experiment was considered the movement distance of the residual nitrogen in a specific layer (Wang et al., 2014; Liu et al., 2020). The ${ }^{15} \mathrm{~N}$ accumulation in the $\mathrm{CW}_{1} \mathrm{~N}_{1}$ treatment peaked in the $40-60 \mathrm{~cm}$ layer, indicating the downward movement distance of 10-20 cm; while the ${ }^{15} \mathrm{~N}$ accumulation in all the APRD treatments in $20-40 \mathrm{~cm}$, indicating a slow movement of ${ }^{15} \mathrm{~N}$ in the soil profile or it moved upward only within $10 \mathrm{~cm}$ (as we did not take soil samples every $10 \mathrm{~cm}$ per layer) as reported previously (Wang et al., 2014, 2019, 2020). In the layers where the ${ }^{15} \mathrm{~N}$ accumulation peaked, the ${ }^{15} \mathrm{~N}$ accumulation in $\mathrm{CW}_{1} \mathrm{~N}_{1}$ decreased by $2.1,8$, and $17.7 \%$, respectively, compared with those in $\mathrm{AW}_{1} \mathrm{~N}_{1}, \mathrm{AW}_{2} \mathrm{~N}_{1}$, and $\mathrm{AW}_{2} \mathrm{~N}_{2}$ treatments. In APRD with the same nitrogen supply level $\left(\mathrm{N}_{1}\right)$, the ${ }^{15} \mathrm{~N}$ accumulation increased in the $0-20$ and $20-40 \mathrm{~cm}$ soil layers, while decreased in the layers below $40 \mathrm{~cm}$ in the $\mathrm{AW}_{2} \mathrm{~N}_{1}$ treatment as compared with $\mathrm{AW}_{1} \mathrm{~N}_{1}$. Under deficient soil water level, the reduction in $50 \%$ of the nitrogen

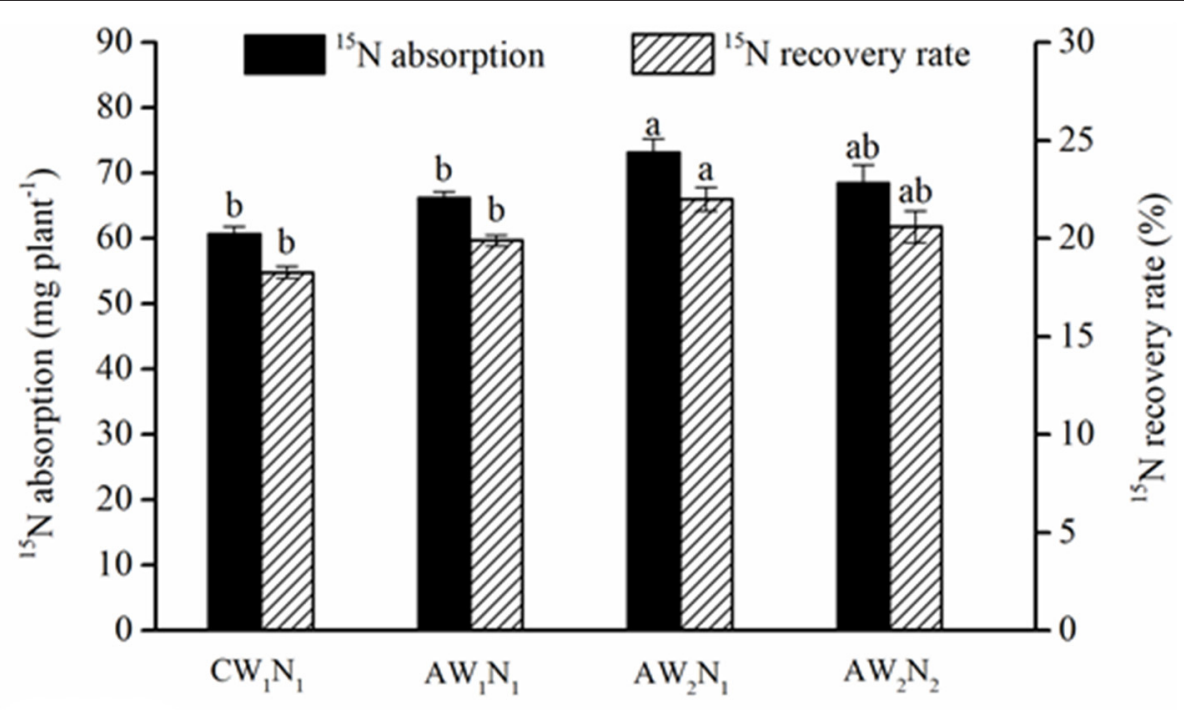

FIGURE 4 | The effects of water and $\mathrm{N}$ supply on ${ }^{15} \mathrm{~N}$ absorption and recovery rate by tomato plants under alternate partial root-zone drip irrigation. Values are the means \pm SE. Different lowercase letters in the columns denote significant differences among the treatments $(P \leq 0.05)$. 


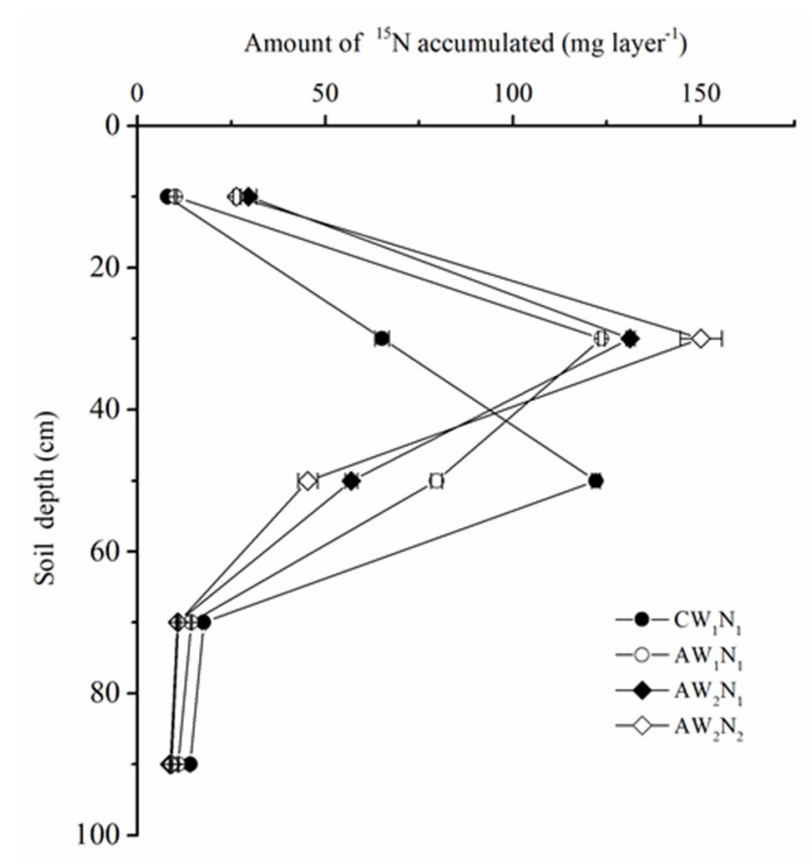

FIGURE 5 | The effects of irrigation and $\mathrm{N}$ supply on the distribution of labeled ${ }^{15} \mathrm{~N}$ in different soil layers under alternate partial root-zone drip irrigation. Values are the means \pm SE.

supply $\left(\mathrm{AW}_{2} \mathrm{~N}_{2}\right)$ increased the ${ }^{15} \mathrm{~N}$ accumulation significantly in the $20-40 \mathrm{~cm}$ layer, but decreased in the $40-60 \mathrm{~cm}$, with no significant difference observed in ${ }^{15} \mathrm{~N}$ accumulation in the other layers compared with $\mathrm{AW}_{2} \mathrm{~N}_{1}$.

\section{Effects of Irrigation and Nitrogen Supply on the ${ }^{15} \mathrm{~N}$ Accumulation and Recovery and Its Loss From the Soil Column}

Under the same amount of water and nitrogen supply, the $\mathrm{AW}_{1} \mathrm{~N}_{1}$ treatment increased the total ${ }^{15} \mathrm{~N}$ recovery by $3.7 \%$, while the ${ }^{15} \mathrm{~N}$ loss rate decreased by $21.3 \%$, and with no significant effects on the ${ }^{15} \mathrm{~N}$ accumulation in the $0-100 \mathrm{~cm}$ soil profile compared with $\mathrm{CW}_{1} \mathrm{~N}_{1}$ (Table 4). Under APRD, the reduction in both the water and $\mathrm{N}$ fertilizer significantly increased the ${ }^{15} \mathrm{~N}$ recovery and accumulation in the soil profile, while the ${ }^{15} \mathrm{~N}$ loss and loss rate decreased by $30 \%$. However, the recovery amount, loss amount, and loss rate were similar between $\mathrm{AW}_{2} \mathrm{~N}_{2}$ and $\mathrm{AW}_{2} \mathrm{~N}_{1}$.

\section{DISCUSSION}

\section{Effect of Irrigation and Nitrogen Supply on Plant Growth, WUE, and NUE}

In the present study, the crop growth and yield were significantly affected by the water and $\mathrm{N}$ application levels and methods. Compared with $\mathrm{CW}_{1} \mathrm{~N}_{1}$, APRD significantly increased the plant biomass and fruit mass under the same level of irrigation and
TABLE 4 | The effects of irrigation and $\mathrm{N}$ treatments on ${ }^{15} \mathrm{~N}$ accumulation and recovery and ${ }^{15} \mathrm{~N}$ loss from the top $0-100 \mathrm{~cm}$ soil layer under alternate partial root-zone drip $\mathrm{N}$ fertigation.

\begin{tabular}{llccc}
\hline Treatments & $\begin{array}{c}\text { Accumulation } \\
\text { amount } \\
\left.\text { (mg column }^{-1}\right)\end{array}$ & $\begin{array}{c}\text { Recovery } \\
\text { amount } \\
\left.\text { (mg column }^{-1}\right)\end{array}$ & $\begin{array}{c}\text { Loss amount } \\
\left.\text { (mg column }^{-1}\right)\end{array}$ & $\begin{array}{c}\text { Loss rate } \\
\text { (\%) }\end{array}$ \\
\hline $\mathrm{CW}_{1} \mathrm{~N}_{1}$ & $226.66 \pm 1.60 \mathrm{~b}$ & $287.47 \pm 2.46 \mathrm{c}$ & $50.33 \pm 2.46 \mathrm{a}$ & $14.90 \pm 0.73 \mathrm{a}$ \\
$\mathrm{AW}_{1} \mathrm{~N}_{1}$ & $231.85 \pm 3.07 \mathrm{~b}$ & $298.21 \pm 2.49 \mathrm{~b}$ & $39.59 \pm 2.49 \mathrm{~b}$ & $11.72 \pm 0.74 \mathrm{~b}$ \\
$\mathrm{AW}_{2} \mathrm{~N}_{1}$ & $239.95 \pm 2.15 \mathrm{a}$ & $310.71 \pm 1.54 \mathrm{a}$ & $25.09 \pm 1.64 \mathrm{c}$ & $7.43 \pm 0.56 \mathrm{c}$ \\
$\mathrm{AW}_{2} \mathrm{~N}_{2}$ & $241.62 \pm 2.14 \mathrm{a}$ & $310.19 \pm 0.72 \mathrm{a}$ & $27.61 \pm 0.92 \mathrm{c}$ & $8.17 \pm 0.22 \mathrm{c}$
\end{tabular}

11.9 gram of ${ }^{15} \mathrm{~N}$-labeled $\mathrm{K}^{15} \mathrm{NO}_{3}$ with the ${ }^{15} \mathrm{~N}$ abundance of $20.3 \%$ provided $337.8 \mathrm{mg}$ ${ }^{15} \mathrm{~N}$ to the $30-40 \mathrm{~cm}$ soil layer in each column. The total recovery amount of ${ }^{15} \mathrm{~N}$ was included in the ${ }^{15} \mathrm{~N}$ accumulated in the $0-100 \mathrm{~cm}$ soil and absorbed by the plant. The total loss of ${ }^{15} \mathrm{~N}$ was calculated from the difference between labeled ${ }^{15} \mathrm{~N}$ introduced by $\mathrm{K}^{15} \mathrm{NO}_{3}$ and the total recovery amount. The data in the table are the means $\pm S E$. The different lowercase letters in the columns denote significant differences among different treatments $(P \leq 0.05)$.

$\mathrm{N}$ application $\left(\mathrm{AW}_{1} \mathrm{~N}_{1}\right)$ (Table 1). Reducing the irrigation water by one-third decreased the plant biomass significantly, while the fruit yield was not affected in $\mathrm{AW}_{2} \mathrm{~N}_{1}$ (Table 1). Therefore, APRD improved the IWUE by $35.6 \%$ without any significant yield reduction (Tables 1, 3). This result is in agreement with the advantages of APRD on saving irrigation water reported in several previous studies (Topak et al., 2016; Sezen et al., 2019; Shu et al., 2020). In addition to the improved IUWE, $\mathrm{N}$ absorption was also enhanced under APRD (Table 3). Even though the biomass decreased significantly, the total $\mathrm{N}$ absorption varied little in $\mathrm{AW}_{2} \mathrm{~N}_{1}$ when compared with that in $\mathrm{CW}_{1} \mathrm{~N}_{1}$ whereas it decreased by only $16 \%$ in $\mathrm{AW}_{2} \mathrm{~N}_{2}$, where a $50 \%$ reduction in the nitrogen fertilizer occurred (Tables 1, 3).

Several reasons could account for the improved IUWE and N absorption under APRD. Under APRI (including APRD), roots could sense the drying soil, and thus generated root-sourced signals to reduce stomatal opening (Kang and Zhang, 2004; Dodd et al., 2006; Liu et al., 2006). It has been demonstrated that the moderate closure of the stomata significantly inhibited the transpiration rate, but showed little effect on photosynthesis, which can stabilize crop growth and yield and improve WUE under APRI with a substantial reduction in irrigation water (Kang and Zhang, 2004). Moreover, under APRI, the root system in the irrigated side can absorb enough water and nutrients to meet the demands of the plants. The roots under APRD became thinner, which increased the root length and surface area in different layers of the soil profile, especially in the middle and lower layers (Figure 3), which is consistent with our previous reports (Chen et al., 2016; Wang et al., 2019; Liu et al., 2020). Several studies reported that APRI could promote the compensatory and balanced growth of roots in different root zones, stimulate the growth and development of root hairs, and induce more root distribution deeper in the soil [refer to review by Kang and Zhang (2004) and Zhang et al. (2014)]. In addition, the repeated drying/wetting cycles improved the soil aeration, which was conducive to 
root activity. The increased root growth and root activity could promote the absorption of water and nutrients by plants (Kang and Zhang, 2004; Sarker et al., 2020). Furthermore, APRI could stimulate organic carbon and $\mathrm{N}$ mineralization and release more mineral $\mathrm{N}$ into the soil solution, which could promote the absorption of $\mathrm{N}$ by plants (Sun et al., 2013; Liu et al., 2020). It was reported that APRI (including APRD) could increase the recovery rate of both the fertilizer$\mathrm{N}$ and residual $\mathrm{N}$ accumulated in the soil (Wang et al., 2014; Hou et al., 2017; Liu et al., 2020). However, the NUE was not improved in the plants under APRD compared with the conventional irrigation at the same $\mathrm{N}$ supply level $\left(\mathrm{AW}_{1} \mathrm{~N}_{1}\right.$, $\mathrm{AW}_{2} \mathrm{~N}_{1}$ vs. $\mathrm{CW}_{1} \mathrm{~N}_{1}$, Table 3), indicating that APRI-plants absorbed excessive $\mathrm{N}$ to ensure growth and yield formation. The NUE increased by $9.4 \%$ in $\mathrm{AW}_{2} \mathrm{~N}_{2}$ compared with that in $\mathrm{CW}_{1} \mathrm{~N}_{1}$ (Table 3). However, it is a general response that the NUE is higher at $\mathrm{N}_{2}$ than at $\mathrm{N}_{1}$ (Xu et al., 2012), indicating that the increased NUE in $\mathrm{AW}_{2} \mathrm{~N}_{2}$ is not an APRDspecific response.

In $\mathrm{AW}_{2} \mathrm{~N}_{1}$, the reduced irrigation water decreased the total biomass, but the yield was similar compared with that of the conventional drip irrigation (Table 1). This indicated that the carbon allocation and remobilization from vegetative organs to fruits was enhanced under APRD. Abscisic acid was suggested to play a vital role in the regulation of plant senescence and carbon remobilization (Yang et al., 2000). Higher leaf ABA concentrations were observed throughout the growing season under APRI compared with that under other treatments (Kirda et al., 2004). The enhanced remobilization of photosynthates and higher harvest index induced by APRD were also observed in our previous studies (Zhang et al., 2014; Shu et al., 2020).

\section{Effect of Irrigation and Nitrogen Supply on Residual Nitrate Loss and Utilization}

It was found that when the ${ }^{15} \mathrm{~N}$ was labeled in the $30-40 \mathrm{~cm}$ layer, APRD reduced the ${ }^{15} \mathrm{~N}$ leaching in the soil column and increased the ${ }^{15} \mathrm{~N}$ accumulation in the $0-40 \mathrm{~cm}$ soil layer by $82.9-141.1 \%$ compared with the conventional drip irrigation (Figure 5). Moreover, APRD increased the absorption and utilization of the labeled $\mathrm{N}$ significantly under $\mathrm{W}_{2}$ coupled with $\mathrm{N}_{2}$ application, and the ${ }^{15} \mathrm{~N}$ loss rate was decreased by $21.3-50.1 \%$, which was the lowest under the deficient irrigation treatments $\left(\mathrm{AW}_{2} \mathrm{~N}_{1}\right.$, $A W_{2} \mathrm{~N}_{2}$ ) (Table 4). These changes were mainly because under APRI (including in APRD form), the water movement in the soil was different from that of conventional irrigation (Kang and Zhang, 2004; Sarker et al., 2019). The heterogeneous distribution of soil moisture induced by APRI reduced the vertical leakage and promoted the lateral infiltration of soil water. In addition, the irrigation amount has been reduced in most cases under APRI (Kang and Zhang, 2004; Zhang et al., 2014; Wang et al., 2019). All these factors contributed to the reduction in nitrate leaching and $\mathrm{N}$ loss under APRI (Wang et al., 2014, 2019). The changes in the ${ }^{15} \mathrm{~N}$ accumulation peaked soil layer also indicated that the leaching of soil nitrate was weakened by APRI (Figure 5). Root activity and root compensatory growth can be increased by APRI, which can lead to an enhanced nutrient absorption (Chen et al., 2016). In addition to the reduced leaching, APRI or APRD could reduce $\mathrm{N}$ loss from the plant-soil system by reducing denitrification and ammonia volatilization (Lei et al., 2009; Han et al., 2014). In the present study, compared with conventional drip irrigation, the total plant biomass, fruit yield, and total $\mathrm{N}$ absorption decreased, whereas the absorption and utilization of labeled $\mathrm{N}$ increased significantly by decreasing the amount of irrigation water and nitrogen application under APRD $\left(\mathrm{AW}_{2} \mathrm{~N}_{2}\right.$ treatment) (Tables 1, 3 and Figure 4).

Wang et al. $(2014,2019)$ labeled ${ }^{15} \mathrm{~N}$ in both the $10-20$ and $40-50 \mathrm{~cm}$ layers and found that with lowering the ${ }^{15} \mathrm{~N}$ labeled layer in the soil profile, the absorption and utilization of ${ }^{15} \mathrm{~N}$ by plants also decreased, while the loss rate of ${ }^{15} \mathrm{~N}$ from the plantsoil column system increased. The downward leaching distance of ${ }^{15} \mathrm{~N}$ was shortened under APRI, and even in the case of labeling the ${ }^{15} \mathrm{~N}$ in the $40-50 \mathrm{~cm}$ soil layer, the ${ }^{15} \mathrm{~N}$ accumulation peaked layer moved upward by $10 \mathrm{~cm}$ (Wang et al., 2014; Hou et al., 2017). However, the recovery and loss rate of ${ }^{15} \mathrm{~N}$ were different between the results reported by Wang et al. $(2014,2019)$ and Hou et al. (2017), probably due to the differences in the plant growth seasons, ${ }^{15} \mathrm{~N}$ labeling amount used, and plant growth conditions. In the present study, ${ }^{15} \mathrm{~N}$ was labeled in the $30-40 \mathrm{~cm}$ layer, which was different from the above previous reports, but close to the depth of $40-50 \mathrm{~cm}$ as reported by Wang et al. (2014) with a close amount of ${ }^{15} \mathrm{~N}$ labeled and the same plant growing season. The results showed that under the $\mathrm{AW}_{2} \mathrm{~N}_{1}$ treatment, the ${ }^{15} \mathrm{~N}$ absorption and loss rate from the plant-soil column system was at 22.01 and $7.43 \%$ (Figure 4 and Table 4), which was $46.7 \%$ higher while $40.8 \%$ lower than those of APRI where ${ }^{15} \mathrm{~N}$ was labeled in the $40-50 \mathrm{~cm}$ layer, and even close to those of APRI where ${ }^{15} \mathrm{~N}$ was labeled in the $10-20 \mathrm{~cm}$ layer with the same level of water and $\mathrm{N}$ supply as reported by Wang et al. (2014). The distribution of the tomato roots was mainly concentrated at the top $0-20 \mathrm{~cm}$ layer (Figure 3) (Wang et al., 2014, 2019; Liu et al., 2020; Shu et al., 2020), thus, the ${ }^{15} \mathrm{~N}$ labeled in the $10-20 \mathrm{~cm}$ layer was more conducive to plant absorption and utilization and to reduce its loss from the plant-soil system (Wang et al., 2014). In the present study, although ${ }^{15} \mathrm{~N}$ was labeled in the $30-40 \mathrm{~cm}$ layer, the ${ }^{15} \mathrm{~N}$ absorption, utilization, and loss rate in the $\mathrm{CW}_{1} \mathrm{~N}_{1}$ were close to those of the conventional irrigation with ${ }^{15} \mathrm{~N}$ labeled in the $10-20 \mathrm{~cm}$ layer as reported by Wang et al. (2014). These results showed that drip irrigation and APRD are more conducive to reducing the leaching and loss of nitrate accumulated in the soil profile, thus promoting plant absorption and its accumulation in soil than the conventional irrigation and APRI (not in the form of APRD here), respectively.

\section{CONCLUSIONS}

Compared with $\mathrm{CW}_{1} \mathrm{~N}_{1}$, under the same amount of water and $\mathrm{N}$ supply, $A W_{1} \mathrm{~N}_{1}$ showed a reduced ${ }^{15} \mathrm{~N}$ leaching in the soil, promoted root growth, and enhanced the absorption of residual nitrate, thus promoted the tomato growth and yield formation. Compared with $\mathrm{CW}_{1} \mathrm{~N}_{1}$, decreasing the irrigation 
water by $34.1 \%$ under APRD $\left(\mathrm{AW}_{2} \mathrm{~N}_{1}\right)$ maintained the total $\mathrm{N}$ absorption, tomato yield, and increased the IWUE by $35.6 \%$, the utilization rate of labeled ${ }^{15} \mathrm{~N}$ by $20.5 \%$, while the loss rate of ${ }^{15} \mathrm{~N}$ from the plant-soil column was decreased by $50.1 \% . \mathrm{AW}_{2} \mathrm{~N}_{2}$ increased the absorption of the labeled ${ }^{15} \mathrm{~N}$ by $12.8 \%$, IWUE by $26.5 \%$, but reduced the yield by $8.8 \%$ compared with those under $\mathrm{CW}_{1} \mathrm{~N}_{1}$. Even though the $\mathrm{N}$ absorption was enhanced, the absorbed-NUE had not improved, indicating that a luxurious absorption of $\mathrm{N}$ occurred under APRD compared with the $\mathrm{CW}_{1} \mathrm{~N}_{1}$ at the same $\mathrm{N}$ supply level. Therefore, it is concluded that APRD can significantly increase IWUE and $\mathrm{N}$ absorption, promote its utilization, and thus, reduce the loss of residual $\mathrm{N}$ that is accumulated in the soil profile. Thus, APRD is a promising technology for sustainable agriculture production even though the NUE in plants has not been improved.

\section{DATA AVAILABILITY STATEMENT}

The raw data supporting the conclusions of this article will be made available by the authors, without undue reservation.

\section{REFERENCES}

Chen, C., Xu, F., Zhu, J. R., Wang, R. F., Xu, Z. H., Shu, L. Z., et al. (2016). Nitrogen forms affect root growth, photosynthesis, and yield of tomato under alternate partial root-zone irrigation. J. Plant Nutr. Soil Sci. 179, 102-110. doi: 10.1002/jpln.201500179

Dodd, I. C. (2009). Rhizposphere manipulations to maximize 'crop per drop' during deficit irrigation. J. Exp. Bot. 60, 2454-2459. doi: 10.1093/jxb/ erp192

Dodd, I. C., Theobald, J. C., Bacon, M. A., and Davies, W. J. (2006). Alternation of wet and dry sides during partial root zone drying irrigation alters root-to-shoot signaling of abscisic acid. Funct. Plant Biol. 33, 1081-1089. doi: 10.1071/FP06203

Du, T. S., Kang, S. Z., Zhang, J. H., and Li, F. S. (2008a). Water use and yield responses of cotton to alternate partial root-zone drip irrigation in the arid area of north-west China. Irrigation Sci. 26, 147-159. doi: 10.1007/s00271-007-0081-0

Du, T. S., Kang, S. Z., Zhang, J. H., Li, F. S., and Yan, B. Y. (2008b). Water use efficiency and fruit quality of table grape under alternate partial root-zone drip irrigation. Agricult. Water Manage. 95, 659-668. doi: 10.1016/j.agwat.2008.01.017

Gathumbi, S. M., Cadisch, G., Buresh, R. J., and Giller, K. E. (2003). Subsoil nitrogen capture in mixed legume stands as assessed by deep nitrogen-15 placement. Soil Sci. Soc. Am. J. 67, 573-582. doi: 10.2136/sssaj2003.5730

Gong, P., Liang, L., and Zhang, Q. (2011). China must reduce fertilizer use too. Nature 473, 284-285. doi: 10.1038/473284e

Han, K., Zhou, C., and Wang, L. (2014). Reducing ammonia volatilization from maize fields with separation of nitrogen fertilizer and water in an alternating furrow irrigationsystem. J. Integr. Agric. 13, 1099-1112. doi: 10.1016/S2095-3119(13)60493-1

Hou, M. M., Jin, Q., Lu, X. Y., Li, J. Y., Zhong, H. Z., and Gao, Y. (2017). Growth, water use, and nitrate-15N uptake of greenhouse tomato as influenced by different irrigation patterns, $15 \mathrm{~N}$ labeled depths, and transplant times. Front. Plant Sci. 8:666. doi: 10.3389/fpls.2017.00666

Hu, T. T., Kang, S. Z., Li, F. S., and Zhang, J. H. (2011). Effects of partial root-zone irrigation on hydraulic conductivity in the soil-root system of maize plant. J. Exp. Bot. 62, 4163-4172. doi: 10.1093/jxb/err110

Jovanovic, Z., and Stikic, R. (2018). Partial root-zone drying technique: from water saving to the improvement of a fruit quality. Front. Sustain. Food Syst. 1:3. doi: 10.3389/fsufs.2017.00003

\section{AUTHOR CONTRIBUTIONS}

L-ZS and W-JZ conceived and designed the experiments. $\mathrm{RL}, \mathrm{P}-\mathrm{FZ}$, and J-RZ performed the experiments. RL and ZC analyzed the data and wrote the manuscript. Y-SW designed the experiments and improved the manuscript. All the authors contributed to the article and approved the submitted version.

\section{FUNDING}

This study was financially supported by the National Natural Science Foundation of China [Grant No. 31572202], the Agricultural Science and Technology Innovation Program [CAAS-ZDRW202002], and the Basic Public Welfare Projects of Zhejiang Province [2017C32082].

\section{ACKNOWLEDGMENTS}

We would like to thank Mr. Ming-Ji Du and Mrs. Shu-Xia Jiang for their assistance in routine management and their other help with the experiment.

Kang, S. Z., Hao, X. M., Du, T. S., Tong, L., Su, X. L., Lu, H. N., et al. (2017). Improving agricultural water productivity to ensure food security in china under changing environment: from research to practice. Agricult. Water Manage. 179, 5-17. doi: 10.1016/j.agwat.2016.05.007

Kang, S. Z., and Zhang, J. H. (2004). Controlled alternate partial root zone irrigation: Its physiological consequences and impact on water use efficiency. J. Exp. Bot. 55, 2437-2446. doi: 10.1093/jxb/erh249

Khalili, F., Aghayari, F., and Ardakani, M. R. (2020). Effect of alternate furrow irrigation on maize productivity in interaction with different irrigation regimes and biochar amendment. Commun. Soil Sci. Plant Anal. 51, 1532-2416. doi: 10.1080/00103624.2020.1733001

Kirda, C., Cetin, M., Dasgan, Y., Topcu, S., Kaman, H., Ekici, B., et al. (2004). Yield response of greenhouse grown tomato to partial root drying and conventional deficit irrigation. Agricult. Water Manage. 69, 191-201. doi: 10.1016/j.agwat.2004.04.008

Lei, Y., Wang, L., Xue, L., Li, Z., and Shang, H. (2009). Effect of alternative irrigation and fertilization on soil ammonia volatilization of summer maize. Transact. Chin. Soc. Agricult. Eng. 25, 41-46.

Li, F., Yu, J., Nong, M., Kang, S., and Zhang, J. (2010). Partial root-zone irrigation enhanced soil enzyme activities and water use of maize under different ratios of inorganic to organic nitrogen fertilizers. Agricult. Water Manage. 97, 231-239. doi: 10.1016/j.agwat.2009.09.014

Liu, F. L., Shahnazari, A., Andersen, M. N., Jacobsen, S. E., and Jensen, C. R. (2006). Physiological responses of potato (Solanum tubersum L.) to partial root-zone drying: ABA signaling, leaf gas exchange, and water use efficiency. J. Exp. Bot. 57, 3727-3735. doi: 10.1093/jxb/erl131

Liu, R., Yang, Y., Wang, Y. S., Wang, X. C., Rengel, Z., Zhang, W. J., et al. (2020). Alternate partial root-zone drip irrigation with nitrogen fertigation promoted tomato growth, water and fertilizer -nitrogen use efficiency. Agricult. Water Manage. 233:106049. doi: 10.1016/j.agwat.2020. 106049

Mancosu, N., Snyder, R., Kyriakakis, G., and Spano, D. (2015). Water scarcity and future challenges for food production. Water 7, 975-992. doi: 10.3390/w7030975

Pérez-Pérez, J. G., Navarro, J. M., Robles, J. M., and Dodd, I. C. (2018). Prolonged drying cycles stimulate ABA accumulation in Citrus macrophylla seedlings exposed to partial rootzone drying. Agricult. Water Manage. 210, 271-278. doi: 10.1016/j.agwat.2018.08.020

Sarker, K. K., Hossain, A., Timsina, J., Biswas, S. K., Kundu, B. C., Barman, A., et al. (2019). Yield and quality of potato tuber and its water productivity are 
influenced by alternate furrow irrigation in a raised bed system. Agricult. Water Manage. 224:105750. doi: 10.1016/j.agwat.2019.105750

Sarker, K. K., Hossain, A., Timsina, J., Biswas, S. K., Malone, S. L., Alam, M. K., et al. (2020). Alternate furrow irrigation can maintain grain yield and nutrient content, and increase crop water productivity in dry season maize in sub-tropical climate of South Asia. Agricult. Water Manage. 238:106229. doi: 10.1016/j.agwat.2020.106229

Sezen, S. M., Yazar, A., and Tekin, S. (2019). Physiological response of red pepper to different irrigation regimes under drip irrigation in the Mediterranean region of Turkey. Sci. Hortic. 245, 280-288. doi: 10.1016/j.scienta.2018.10.037

Shahnazari, A., Liu, F. L., Andersen, M. N., Jacobsen, S. E., and Jensen, C. R. (2007). Effects of partial root-zone drying on yield, tuber size and water use efficiency in potato under field conditions. Field Crops Res. 100, 117-124. doi: 10.1016/j.fcr.2006.05.010

Shu, L. Z., Liu, R., Min, W., Wang, Y. S., and Zhu, J. R. (2020). Regulation of soil water threshold on tomato plant growth and fruit quality under alternate partial root-zone drip irrigation. Agricult. Water Manage. 238:106200. doi: 10.1016/j.agwat.2020.106200

Sun, Y., Yan, F., and Liu, F. (2013). Drying/rewetting cycles of the soil under alternate partial root-zone drying irrigation reduce carbon and nitrogen retention in the soil-plant systems of potato. Agricult. Water Manage. 128, 85-91. doi: 10.1016/j.agwat.2013.06.015

Tafteh, A., and Sepaskhah, A. R. (2012). Yield and nitrogen leaching in maize field under different nitrogen rates and partial root drying irrigation. Int. J. Plant Prod. 6, 93-114.

Topak, R., Acar, B., Uyanöz, R., and Ceyhan, E. (2016). Performance of partial root-zone drip irrigation for sugar beet production in a semiarid area. Agricult. Water Manage. 176, 180-190. doi: 10.1016/j.agwat.2016. 06.004

Wang, C. H., Shu, L. Z., Yu, H. M., Zhu, P. F., Tang, J. H., and Zhou, Q. W. (2020). Effects of partial root-zone irrigation and nitrogen forms on the movement of nitrate in deep subsoil and its utilization by tomato plants. Eur. J. Soil Sci. 71, 448-458. doi: 10.1111/ejss.12850

Wang, C. H., Shu, L. Z., Zhou, S. L., Yu, H. M., and Zhu, P. F. (2019). Effects of alternate partial root-zone irrigation on the utilization and movement of nitrates in soil by tomato plants. Sci. Hortic. 243, 41-47. doi: 10.1016/j.scienta.2018.08.006

Wang, C. H., Zhu, P. F., Shu, L. Z., Zhu, J. Z., and Yu, H. M. (2014). Effects of alternate partial root-zone irrigation and nitrogen forms on utilization and movement of nitrate in soil. Transact. Chin. Soc. Agricult. Eng. 30, 92-101. doi: 10.3969/j.issn.1002-6819.2014.11.012
Wang, Y., Liu, F., Neergaard, A. D., Jensen, L. S., Luxhi, J., and Jensen, C. R. (2010). Alternate partial root-zone irrigation induced dry/wet cycles of soils stimulate $\mathrm{N}$ mineralization and improve $\mathrm{n}$ nutrition in tomatoes. Plant Soil 337, 167-177. doi: 10.1007/s11104-010-0513-0

Xu, G. H., Fan, X. R., and Miller, A. J. (2012). Plant nitrogen assimilation and use efficiency. Annu. Rev. Plant Biol. 63: 153-182. doi: 10.1146/annurev-arplant-042811-105532

Yactayo, W., Ramírez, D. A., Gutiérrez, R., Mares, V., Posadas, A., and Quiroz, R. (2013). Effect of partial root-zone drying irrigation timing on potato tuber yield and water use efficiency. Agricult. Water Manage. 123, 65-70. doi: 10.1016/j.agwat.2013.03.009

Yang, J. C., Zhang, J. H., Huang, Z. L., Zhu, Q., and Wang, L. (2000). Remobilization of carbon reserves is improved by controlled soildrying during grain filling of wheat. Crop Sci. 40, 1645-1655. doi: $10.2135 /$ cropsci2000.4061645x

Zhang, Q., Wu, S., Chen, C., Shu, L. Z., Zhou, X. J., and Zhu, S. N. (2014). Regulation of nitrogen forms on growth of eggplant under partial root-zone irrigation. Agricult. Water Manage. 142, 56-65. doi: 10.1016/j.agwat.2014.04.015

Zhu, Z. L., and Chen, D. L. (2002). Nitrogen fertilizer use in China contributions to food production, impacts on the environment and best management strategies. Nutr. Cycling Agroecosyst. 63, 117-127. doi: 10.1023/A:1021107026067

Conflict of Interest: The authors declare that the research was conducted in the absence of any commercial or financial relationships that could be construed as a potential conflict of interest.

Publisher's Note: All claims expressed in this article are solely those of the authors and do not necessarily represent those of their affiliated organizations, or those of the publisher, the editors and the reviewers. Any product that may be evaluated in this article, or claim that may be made by its manufacturer, is not guaranteed or endorsed by the publisher.

Copyright $\odot 2021 \mathrm{Liu}, \mathrm{Zhu}$, Wang, Chen, Zhu, Shu and Zhang. This is an openaccess article distributed under the terms of the Creative Commons Attribution License (CC BY). The use, distribution or reproduction in other forums is permitted, provided the original author(s) and the copyright owner(s) are credited and that the original publication in this journal is cited, in accordance with accepted academic practice. No use, distribution or reproduction is permitted which does not comply with these terms. 